\title{
Democratisation of local government planning in Bangladesh
}

\section{Commonwealth Journal of Local Governance}

Issue 20: December 2017

http://cjlg.epress.lib.uts.edu.au

\author{
Shuvra Chowdhury \\ Department of Public Administration \\ University of Rajshahi \\ Bangladesh \\ Email: shuvrachowdhury@ru.ac.bd
}

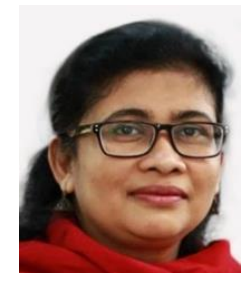

\begin{abstract}
This article explores the participatory planning and participatory budgeting processes of Bangladesh. These processes, seen as 'social accountability measures', were introduced by the Local Government (Union Parishad) Act, 2009. This study used a qualitative case-study methodology, backed by secondary documentary analysis, to assess how the processes were working in six union parishads (the lowest tier of government in Bangladesh). On the basis of both primary and secondary data, the study found that involvement of non-governmental organisations was an effective method of enhancing the capacity of union parishad functionaries to implement participatory planning and participatory budgeting. Positive outcomes observed included increased people's participation, identification of socio-economic concerns, increased trust in elected representatives, increased transparency, changes in patterns of service delivery and improved viability of direct fund transfers to local government institutions. However, challenges to local planning and budgeting were also identified: failure to link policy, planning and budgeting due to a lack of capacity among local elected and government officers, structural mismatches between local planning and budgeting and corresponding processes at regional and national level, resource constraints, and local political interference.
\end{abstract}

Keywords: Participatory planning, participatory budgeting, social accountability, local government, decentralisation in Bangladesh

\section{Introduction}

Decentralisation efforts are not new in Bangladesh. Since independence in 1971, local government institutions (LGIs) have been the plaything of successive governments, each introducing a new system 
(Panday and Assaduzzaman 2011; Ahmed 2012). The present Awami League ${ }^{1}$ government came to power in 2008 and enacted laws which provided for comprehensive public participation in the planning process. Among these, the Local Government (Union Parishad) ${ }^{2}$ Act 2009 (hereinafter the 'UP Act 2009') offers people the opportunity for direct engagement at ward level to identify problems related to their livelihoods (GoB 2009). This article explores the participatory planning (PP) and participatory budgeting (PB) process within union parishads (UPs), the lowest tier of government in Bangladesh.

\section{Objectives of the research}

The paper addresses three research questions:

1. How are the processes of PP and PB involving people in the decision-making process of UPs in Bangladesh?

2. How are the present processes of PP and PB, at the local level, related to nationallevel policy, planning and budgeting in Bangladesh?

3. How, and to what extent, do the processes of PP and PB ensure social accountability at the local level?

The paper's findings are based on examination of participatory/open budgeting processes in six UPs in Bangladesh. These are Hariyan and Gogram UPs from the Rajshahi District; Ghurka and Hatikumrul UPs from the Sirajganj District, and Kakina and Vadai UPs from the Lalmonirhat District.

\section{Literature review}

Scholars have categorised decentralisation reforms into two 'waves'. The 'first wave', or 'first generation of decentralisation', included reform of integrated national planning strategies, which was initiated during the late 1960s to mid-1970s in many developing countries (Cheema and Rondinelli 2007; Olsen 2007; Chowdhury 2015). This first wave of decentralisation had little impact in terms of administrative change and failed in many parts of Asia and Africa (Bergh 2004). Some of the most important causes of this failure, according to Olsen (2007), were:

1. lack of people's participation

2. lack of capacity of local administration to take up the new responsibilities

3. lack of redistribution of wealth, status and power

4. poor policy implementation.

Olsen maintains that this first generation of decentralisation was poorly implemented due to: a lack of clear objective; inadequate resources; a shortage of skilled manpower, and general resistance from senior bureaucrats among other reasons. However, by the beginning of the 1990s a 'second wave' or 'second generation of decentralisation' was observed in an increasing number of developing countries

\footnotetext{
${ }^{1}$ The political party which has been governing Bangladesh since 2008.

${ }^{2}$ A union parishad is an assembly of elected people.
} 
as 'decentralisation in the variant of devolution'(Olsen 2007, p. 3), i.e. the transfer of powers to elected local governments (Olsen 2007; Cheema and Rondinelli and 2007). The second generation moved from reform to restructuring, aiming to shift decision-making from the centre to the periphery, rather than just change the decision-making process at the centre.

Generally, four types of decentralisation in the second generation can be observed: (1) political (2) administrative (3) fiscal and (4) market (Panday and Asaduzzaman 2011). Political decentralisation means groups of people at different levels of government - central, meso and local - are empowered to make decisions related to issues that affect them. Administrative decentralisation means different levels of government administer resources and matters delegated to them, generally through a constitution. Fiscal decentralisation involves the dispersal to other levels of government of previously-concentrated powers to tax and generate revenues; for example, local governments may be given the power to raise and retain financial resources. Market decentralisation (divestment or privatisation) occurs when government privatises or deregulates private functions (Yuliani 2004).

The European Commission (2007) suggests that fiscal and political decentralisation will bring about devolution, while administrative decentralisation leads to deconcentration. However, in practice the second wave of decentralisation was typically confined to hierarchical government structures and bureaucracies (European Commission 2007). Later, its reach was broadened to include political power-sharing, democratisation, market liberalisation and expansion of the scope for private sector decision-making (Olsen 2007; Cheema and Rondinelli 2007). During the 1990s, public participation, often through non-governmental organisations (NGOs), was adopted as a measure of decentralisation, with the effect of making governance more open (Cheema and Rondinelli 2007).

Figure 1 below illustrates the complexity and inter-linkages of decentralisation reform processes, which focused on:

1. devolution of power

2. engagement of civil society organisations (CSOs) in participation mechanisms, and monitoring 'downward accountability' - i.e. elected and bureaucratic representatives' accountability to citizens

3. local economic development based on the expressed needs and wishes of the public organised via broad coalitions (e.g. local governments and NGOs; local governments and the private sector; local governments, NGOs, the private sector and support institutions)

4. public sector reform, with local civil servants recognised as key actors in delivering sustainable and viable local-level development. 
Figure 1: Decentralisation and state reform

\begin{tabular}{|c|c|c|c|}
\hline \multicolumn{4}{|c|}{$\begin{array}{c}\text { 1990s - Second wave of decentralisation: } \\
\text { new model based on four building blocks }\end{array}$} \\
\hline Local democracy & Local governance & $\begin{array}{c}\text { Local economic } \\
\text { development }\end{array}$ & State modernisation \\
\hline $\begin{array}{c}\text { Devolution of powers to } \\
\text { elected local bodies with } \\
\text { relative autonomy }\end{array}$ & $\begin{array}{c}\text { Based on civil society } \\
\text { participation and downward } \\
\text { accountability }\end{array}$ & $\begin{array}{c}\text { Pro-poor } \\
\text { decentralised service } \\
\text { delivery }\end{array}$ & $\begin{array}{c}\text { Public sector reform, with } \\
\text { focus on local civil service }\end{array}$ \\
\hline
\end{tabular}

Source: Olsen (2007)

The new decentralisation model concentrates on devolution of power for the delivery of pro-poor services at the local level. In addition, local economic development emphasises coalitions of CSOs, NGOs, other private sector stakeholders and support institutions, all working alongside LGIs (Olsen 2007).

\section{Why promote PP and PB processes in local government?}

Strategic planning is an important tool for overseeing the functions of an organisation, including organising, staffing, decision-making, coordinating, reporting and budgeting (Rosenbloom 1989); it is also an essential mechanism to enable local government to determine the activities that will best achieve its mandate. There are two main approaches to plan preparation: 'bottom-up' and 'top-down' (Obaidullah 1999). Bottom-up planning includes involving local actors in setting priorities for local development. Top-down approaches involve selected projects from a higher level of government being sent to local-level governments for implementation (Obaidullah 1999). In contrast, in PP and PB processes citizens are directly involved in making policy decisions (Rahman 2005a). PP and PB were first introduced by the Brazilian Worker's Party and the first participatory budget process was implemented in Porto Alegre in Brazil in 1989 (Shah, 2007). These processes have now been adopted in many other regions of the world including Asia, Europe and America. Discussions in the literature on the benefits of PP and PB within LGIs can be summarised as follows:

\section{a. Democratisation of local government}

Olsen (2007) argues that the political processes of PP and PB establish mandatory people's participation in local decision-making. PP and PB processes thus facilitate other activities vital to democracy, including: political institution formation; citizen engagement in local development activities and representation through their elected representatives; participation of citizens and CSOs in public decision-making processes; autonomy over the spending of local government's own resources; and representation through an election process. 


\section{b. Better policy outcomes}

PP and PB within LGIs constitute a bottom-up approach to planning, seeing policy processes and planning and budgeting as interconnected and interdependent (Chowdhury 2015). PB leads to a specific focus on meeting local need, and as Cabannes (2015, p. 257) noted: "The first and probably most important finding is that participatory budgeting always prioritise[s] and vote[s] for basic service projects, and is a powerful mechanism for basic service delivery at the local level." Locallevel decision-making can also lead to better policy outcomes: "In the absence of effective decisionmaking processes, policy-making and planning are disconnected from each other and from budgeting, and they are not constrained by resource availability or by strategic priorities" (World Bank 1998, pp. 31-32). Thus implementing PP and PB at the local level reflects a willingness of government to create an equitable distribution of scarce resources and promote public learning and transparency (Wampler 2007). More importantly, along with structural elements, PP and PB encourage the congregational elements of the local government system, defined as the "institutionalization of integration among all stakeholders working for local governance" (Waheduzzaman and Alam 2015, p. 262).

\section{c. Enhanced accountability of local government}

Social accountability may be defined as the mechanism that establishes accountability of public organisations through direct civic engagement. It is therefore important that public organisations should have participatory mechanisms through which citizens can interact with both political and administrative personnel, ensuring they answer for any action or inaction. The political and fiscal decentralisation processes of PP and PB are regarded as social accountability mechanisms (Malena et al. 2004). In these processes citizens are directly involved in prioritising, scrutinising and monitoring public spending (Chowdhury 2015). This creates a new type of relationship between local government and its citizenry. As Mulgan (2002, p. 3) states: “....we can take it to refer to a relationship in which one party, the holder of accountability, has the right to seek information about, to investigate and to scrutinise the actions of another party, the giver of accountability".

\section{How the system works}

At present, the UP is the lowest tier of the rural local government system of Bangladesh. The other two tiers are upazila parishad (hereinafter 'UZP'), at the sub-district level, and zila parishad (ZP) at the district level. All these tiers have elected bodies. In accordance with Sections 9 and 10 of the UP Act 2009, each UP is divided into nine wards. Its representatives comprise one elected chair and 12 elected members: one elected from each of the nine wards, and three women elected for three seats (one for every three wards) reserved exclusively for women.

The UP Act 2009 was brought in following the success of donor-driven projects relating to local governance (Chowdhury 2015). Based on the success and good practice learnings of a pilot project in 
Bangladesh's Sirajganj district (Vijayalakshmi 2002), the Government of Bangladesh (GoB) implemented its nation-wide Local Governance Support Programme (LGSP-I) from 2007-2011. The programme is now in its third wave, LGSP-III (2017-2022), with financial assistance from the World Bank. A key feature of the LGSP is that the selection of projects and the budget allocated is determined and finalised through direct civic engagement.

There are four types of UP committee (see Table 1): ward committee (WC), planning committee (PC), standing committee (SC) and union development and coordination committee (UDCC).

Table 1: Committee structure for UP planning and budgeting

\begin{tabular}{|c|c|c|c|}
\hline$W C=9$ & $P C=1$ & $S C=13$ & UDCC $=1$ \\
\hline $\begin{array}{l}\text { At least seven persons } \\
\text { within the ward in } \\
\text { question, including elected } \\
\text { ward member, social } \\
\text { worker, beneficiary, school } \\
\text { teacher, technical experts } \\
\text { etc. }\end{array}$ & $\begin{array}{l}\text { A member of the UP } \\
\text { convenes or chairs the } \\
\text { committee. Committee } \\
\text { members include the other } \\
\text { UP members, the UP } \\
\text { secretary and the head of } \\
\text { the other local } \\
\text { representatives of central } \\
\text { government offices those } \\
\text { are transferred to subdistrict } \\
\text { or UP level, as well as any } \\
\text { development planning } \\
\text { expert the committee } \\
\text { chooses to invite. }\end{array}$ & $\begin{array}{l}\text { Each SC should be } \\
\text { composed of: UP } \\
\text { members and chair, } \\
\text { including UP women } \\
\text { members; co-opted } \\
\text { members; subject } \\
\text { experts; and local } \\
\text { people with relevant } \\
\text { skills. }\end{array}$ & $\begin{array}{l}\text { Chaired by the UP } \\
\text { chair. Other members } \\
\text { include UP members, } \\
\text { UZP officers, UP } \\
\text { officers, and } \\
\text { representatives with } \\
\text { specific skills such as } \\
\text { social workers, NGO } \\
\text { officials and school } \\
\text { teachers. }\end{array}$ \\
\hline
\end{tabular}

The members of the WC are assigned to preparatory tasks for each ward shava (i.e. ward meeting or 'WS'). The UP is responsible for directing the members of the WC to publish the date and discussion topic of the WS at least seven days before the meeting - by distributing leaflets, invitation letters and notices. According to Articles 4 and 5 of the UP Act 2009, each WC is supposed to organise a WS at least twice a year, which should include all citizens on the voter roll. The WC is responsible for providing detailed information to people about policies and spending priorities of their local government, while citizens are supposed to identify problems and resources, determine preferences, select strategies and distribute responsibilities (Chowdhury 2015). The steps in the process are described below, and summarised in Figure 2.

Figure 2: Steps in the PP process for UPs in Bangladesh

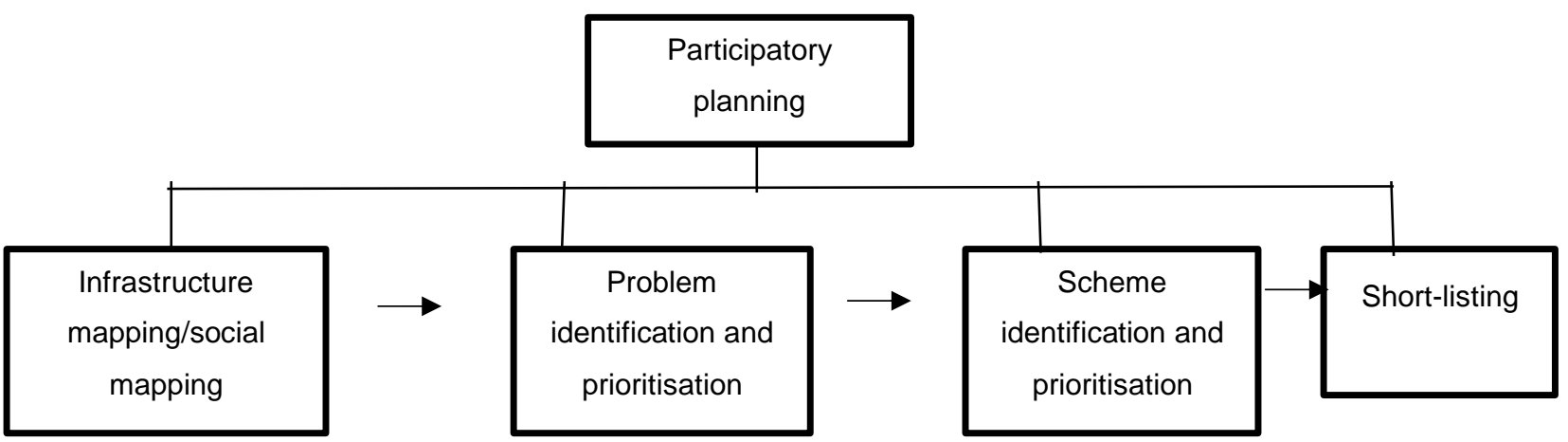

Source: GoB (2012a) and cited in Rahman 2005b. 
Phase 1: plan formulation. At the WS, social mapping is used to establish socio-economic levels in the community and identify pockets of relative poverty, so that mechanisms for political accountability can be developed. It is the duty of the members of the WC to divide the lay participants into small groups, and support participants to identify their development needs, on the basis of spending priorities, at the WS meeting.

Phase 2: independent budget analysis. This phase concerns analysis and scrutiny. Sector-specific plans and projects are prepared by technical experts. The planning committee is then responsible for sending these WS plans to the relevant SCs, which must then prioritise the demands and schemes, bearing in mind the availability of resources, and prepare a five-year plan. The UP must follow this five-year plan when preparing its annual development plan. The annual plan and a budget statement are then sent to the UDCC and the UP for final approval. At the UDCC meeting, government officers from the higher tier - UZP level - are supposed to present and approve the projects that were agreed at the WS.

The UP (Development Plan) Circular 2013 also stipulates additional plans to be included in UP development plans (GoB 2013):

- plans/projects transferred from UZP and ZP to UP

- central government projects where implementation is needed at UP level

- NGO projects where implementation is needed at UP level.

Phase 3: public expenditure monitoring project implementation. In this phase, approved projects are implemented under the oversight of a scheme supervision committee (SSC). For each UP, an open budget meeting (OBM) should be held at least twice a year. ${ }^{3}$ Following this, the UP is responsible for organising a public session where it presents a yearly budget to the SC and people, a minimum of 60 days before the end of the financial year. The finalised UP budget is then sent to the upazila nirbahi officer ('UNO' - ie chief local government administrative officer) at the UZP, for approval. The UNO of each UZP collates all the approved UP plans and sends these to the local offices of government ministries and to the district commissioner, who is the administrative head of the ZP.

Phase 4: monitoring and evaluation. In this phase, approved plans for the budget year and information about projects implemented the previous year must be displayed in public places. This stage offers citizens the opportunity to discuss the budgeted activities and their results, and to demand accountability from their representatives.

\footnotetext{
${ }^{3}$ Public expenditure monitoring and project implementation related data are presented at the OBM, which is open to all members of the UP.
} 


\section{Research methodology}

Adopting a case-oriented, qualitative research strategy, this study included fieldwork in six UPs of the Rajshahi, Sirajganj and Lalmonirhat districts, and examined both primary and secondary data. Secondary data were collected from different published and unpublished sources including books, journal articles, newspapers, research reports, working paper and internet browsing. Primary data were collected in UPs, based on interviews with the UP Chair, UP secretary, other UP members and other knowledgeable key informants, focusing on their planning and budgeting processes as the main focus of this study. Among nine wards of each UP, wards 1, 4 and 7 were selected to ensure an equal number of male and female UP functionaries for the interview process. The fieldwork took place between January, 2012 to June, 2014, during the second phase of the GoB's LGSP programme ('LGSPII').

Table 2: Respondents of the study

\begin{tabular}{|c|c|c|c|c|c|}
\hline Type of respondent & $\begin{array}{l}\text { Number of } \\
\text { respondents in } \\
\text { each of the three } \\
\text { wards }(1,4 \text { and } 7)\end{array}$ & $\begin{array}{l}\text { Number of } \\
\text { respondents } \\
\text { selected }\end{array}$ & $\begin{array}{l}\text { Number of } \\
\text { respondents } \\
\text { per UP }\end{array}$ & Sample size & $\begin{array}{l}\text { Actual } \\
\text { number of } \\
\text { interviewees }\end{array}$ \\
\hline UP chair & \multicolumn{2}{|l|}{$\mathrm{N} / \mathrm{A}$} & $1(100 \%)$ & 6 & 6 \\
\hline UP secretary & \multicolumn{2}{|l|}{$\mathrm{N} / \mathrm{A}$} & $1(100 \%)$ & 6 & 6 \\
\hline Ward member & 1 & 1 & $3(33 \%)$ & $18(6 \times 3)$ & 17 \\
\hline $\begin{array}{l}\text { Reserved seat for female } \\
\text { member }\end{array}$ & $\begin{array}{l}1 \text { each from the three } \\
\text { wards) }\end{array}$ & 1 & $3(100 \%)$ & $18(6 \times 3)$ & 18 \\
\hline $\begin{array}{l}\text { Members of the public } \\
\text { who had participated in } \\
\text { WS or OBM }\end{array}$ & $\begin{array}{l}\text { Interviewees selected } \\
\text { from names in WS } \\
\text { resolution book and } \\
\text { OBM participants' list }\end{array}$ & $\begin{array}{l}4 \text { ( } 2 \text { males and } 2 \\
\text { females from } \\
\text { each ward) }\end{array}$ & $12((2+2) \times 3)$ & $72(12 \times 6)$ & 79 \\
\hline $\begin{array}{l}\text { Other key informants } \\
\text { (depending on } \\
\text { availability) }\end{array}$ & \multicolumn{2}{|c|}{$\begin{array}{l}\text { WC members, UDCC members, district } \\
\text { facilitator of LGSP-II project, deputy } \\
\text { director of local government (DDLG), } \\
\text { project implementation officer (PIO), } \\
\text { social welfare officer (SWO), upazila } \\
\text { women's affairs officer (UWAO), chair } \\
\text { and vice-chair of upazila parishad, } \\
\text { upazila nirbahi officer (UNO), local } \\
\text { political leaders and others }\end{array}$} & 6 & $36(6 \times 6)$ & 36 \\
\hline Total & \multicolumn{4}{|c|}{150} & 162 \\
\hline
\end{tabular}

The data in Table 2 show that a total of 47 key informant interviews were held in a total of six UPs, including: the chair (6); secretary (6), ward members (17) and female ward members (18) for collection of primary data. Interviews were also held with 79 participating members of the public. Further, primary data was collected through direct observations of PP and PB processes. Secondary sources reviewed included: UP minutes; UP resolutions; proposals for ward budgets put forward by citizens at WSs: the constitutions of SCs, WCs, PCs and UDCCs and their activities; yearly budget sheets; real income expenditure statements of UPs for the financial year 2012-13; and UDCC resolutions. In addition to this, the data in Table 2 show that a total of 36 key informant interview were 
held among the public and government officials of sub-district and district level. Additionally, in each ward, two focus group discussions were held (one for men and one for women) for those who did not participate in the WS or OBM. These focus groups included participants of a total of 323 respondents from a total 36 FGD sessions.

\section{Positive results of the new PP and PB systems}

The author now turns to the findings of this research project.

\section{Popular participation has been achieved}

This study corroborates the findings of Sarkar and Dutta (2011): legal enforcement has enhanced citizens' access to local-level plan and budget preparation in Bangladesh. Although this study found three types of WS meeting, including fake and semi-fake (see Table 3), it was evident that legitimised citizen participation is ongoing in UPs. A satisfactory number ${ }^{4}$ of people participated in the local planning process. Like Ullah and Pongquan (2011), this study found that the new system of UP planning has been facilitating democratisation. People's access to these processes - WSs and OBMs is creating a pathway for mass participation in decision-making at the local level.

Table 3: Types of PP and PB processes observed in the six UPs studied

\begin{tabular}{|c|c|c|c|c|c|c|c|c|}
\hline \multirow[t]{2}{*}{ District } & \multirow[t]{2}{*}{ UZP } & \multirow[t]{2}{*}{ UP } & \multicolumn{3}{|c|}{ WS held } & \multirow{2}{*}{$\begin{array}{c}\text { PC } \\
\text { constituted }\end{array}$} & \multirow{2}{*}{$\begin{array}{c}\mathrm{SC} \\
\text { constituted }\end{array}$} & \multirow{2}{*}{$\begin{array}{c}\text { UDCC } \\
\text { constituted }\end{array}$} \\
\hline & & & $\begin{array}{c}\text { Social } \\
\text { mapping } \\
\text { and WS }\end{array}$ & $\begin{array}{c}\text { Cultural } \\
\text { programme }\end{array}$ & 'Fake'5 WS & & & \\
\hline \multirow[t]{2}{*}{ Lalmonirhat } & Kaliganj & Kakina & W1, W4 & W7 & & No & Yes & No \\
\hline & Aditmari & Vadai & $\mathbf{x}$ & $\mathbf{x}$ & WI, W4, W7 & No & Yes & No \\
\hline \multirow[t]{2}{*}{ Rajshahi } & Paba & Hariyan & W1, W4, W7 & $x$ & $\mathbf{x}$ & No & Yes & No \\
\hline & Godagari & Gogram & W1, W7 & $x$ & W4 & No & Yes & Yes \\
\hline \multirow[t]{2}{*}{ Sirajganj } & Ullapara & Hatikumrul & W1 & $\mathbf{x}$ & W4, W7 & No & Yes & No \\
\hline & Raiganj & Ghurka & W4 & $x$ & W1, W7 & No & Yes & No \\
\hline
\end{tabular}

Source: Documentation review, interview and focus group data (2012-14).

Note: 'W' stands for 'ward'.

\section{NGOs enhance effectiveness}

From the data obtained from FGDs and interviews with key informants it was found that the congregational elements introduced by $\mathrm{NGOs}^{6}$ were a significant factor in the outcomes of the planning process. This was evident in two ways:

\footnotetext{
${ }^{4}$ The quorum for a WS is $5 \%$ of the total voters. This study found that the quorum was achieved in those wards organising genuine shavas.

${ }^{5}$ For example, the UP functionaries organised a tea party or cultural programme and called it a WS. They did so in order to be able to record attendee signatures in the meeting register, which was a donor requirement before releasing project funds.

${ }^{6}$ For example, a local NGO, named Shacheton, received funding from the Swiss Agency for Development and Cooperation to run a project named Sharique working for political empowerment of people in Rajshahi district.
} 
Firstly, NGOs provided 'missing links' in the process of planning and budgeting. It was clear that, in many cases, UP officers' capacity to undertake social mapping was insufficient, due to their lack of education and training. They often refused to attend the social mapping events before the WS meetings. In such cases, the first three stages of planning (formulation, analysis and implementation of projects) had previously been paper exercises undertaken to secure LGSP-II funds. The present study found that $70.2 \%$ (33 of 47) of UP officers, despite having completed secondary school, had not been provided with training on the operational side of budgeting (defining budget cycles, making revenue estimates, classifying expenditure as recurring or capital, conducting open budget hearings etc.). This meant that when they had to carry out such roles, they did not know what to do. However, NGOs filled the gap, by providing training and offering assistance via their expert staff.

Secondly, NGOs filled leadership gaps. At the most basic level, in some UPs it was NGO officers who, along with the UP members, formed the WCs and organised the WSs. More significantly, NGOs helped UP officers capitalise on the new system of budgeting and planning. Local officials were supported to make strategic plans, to use their UPs' financial resources and to collect taxes which had previously been unlevied or uncollected. For example, NGO officers motivated and trained UP officers to collect property tax, to form WCs and to organise WSs and budget meetings etc. In these cases, the social mapping and decision-making processes took place at the same time, as the NGO officials and ward members facilitated the WS meetings.

\section{Rural poor participate effectively}

It was clear from the study, and interviews with general citizens that ordinary people - including villagers with limited formal education - were fully able to prioritise between policies which affected their livelihoods. Table 4 provides a case-study of such decisions made in Hariyan UP. They had prioritised demands against specific allocation on donors or NGOs. People had information about monetary allocation from various funding agencies and prioritised demands of reconstruction of roads, tube well placement, distribution of ring slub, skills development, training and distribution of materials to women. These demands were documented at a WS meeting. The data also showed how many voters would be benefitted from the project implementation.

Overall, the data gathered by this study revealed that citizens prioritised their needs as follows: development and infrastructural programmes (62\%), public welfare services (64\%), social safety net benefits (23\%), and support for self-employment (8\%). Participants insisted that their local governments include their names on registers for social safety net programmes, cultural and sports activities and school parent-teacher meetings. Thus, their input into the budgeting and planning processes was both helpful and effective, not only in improving policies but also in accessing services from which they had been left out. 
Table 4: Case-study: WS plans of Ward 7, Hariyan UP, for 2013-14

\begin{tabular}{|l|l|l|l|l|}
\hline Projects & Project location & $\begin{array}{l}\text { Planned } \\
\text { budget }\end{array}$ & $\begin{array}{l}\text { Income } \\
\text { source }\end{array}$ & $\begin{array}{l}\text { Number of } \\
\text { beneficiaries }\end{array}$ \\
\hline $\begin{array}{l}\text { Road } \\
\text { construction }\end{array}$ & $\begin{array}{l}\text { Road from Charkhidirpur Samrat's } \\
\text { house to Sumon's house a } \\
\text { Road from Charkhidirpur Babu's house } \\
\text { to Alal's house a }\end{array}$ & 22,632 Taka7 & LGSP 1\% & 1,000 \\
\hline $\begin{array}{l}\text { Tube well } \\
\text { placement }\end{array}$ & Various (30) locations within the ward & 385,666 Taka & HYSAWA & 1,500 \\
\hline $\begin{array}{l}\text { Distribution of } \\
\text { ring slub }\end{array}$ & $\begin{array}{l}\text { Various villages within the ward (a total } \\
\text { of 100) }\end{array}$ & 66,666 Taka & LGSP 1\% & 500 \\
\hline $\begin{array}{l}\text { Skills } \\
\text { development, } \\
\text { training and } \\
\text { distribution of } \\
\text { materials to } \\
\text { women }\end{array}$ & $\begin{array}{l}\text { - Agricultural training (20 people) } \\
\text { Sewing machine training and } \\
\text { distribution of sewing machines }(20 \\
\text { people) } \\
\text { Distribution of fishing nets (20 } \\
\text { people) b }\end{array}$ & $113,888 T$ Taka & $\begin{array}{l}\text { LGSP and } \\
\text { Sharique } \\
\text { project }\end{array}$ & 150 \\
\hline $\begin{array}{l}\text { Construction of } \\
\text { culvert }\end{array}$ & \begin{tabular}{l} 
East side of Chartaranagar \\
\cline { 1 - 3 }
\end{tabular} & 226,321 Taka & LGSP 1\% & - \\
\hline
\end{tabular}

Source: Ward plan review (2014)

Note a) Refers to place names, named for nearby landmark buildings

Note b) Benefits to 60 people reviewed during fieldwork from a total of 150 .

\section{Social accountability: local power is redistributed}

Promisingly, this study found that extensive publicity was undertaken by UP officers encouraging voters to attend their local WS and OBM. In the project evaluation and monitoring stage, the researchers also found spontaneous budget discussion at OBMs, when the performance report for the previous financial year was laid before the meeting. The UP officers provided information to the meetings generously, including the ward 'demand' lists of services requested, budget statements and income-expenditure statements. Many of these had also been available through multimedia, or displayed on a bulletin board at the UP headquarters, during the year: but presenting them in the OBM context offered an opportunity for feedback and not merely one-way information.

Citizens at the meeting seized their opportunities to question UP chairs and question their decisions. In addition, printed copies of the budget were distributed to all citizens within the UPs which organised OBMs, to inform those who had not attended the earlier WS. From the sample studied, it appears that people's right to ask questions at OBMs has made the ward members more responsive to voters, and the UP chair more responsive to the ward members. The WMs expressed No Confidence 9 in the UP chair for not following prescribed procurement processes, and although they had insuffient support to carry the motion, the example demonstrated elected members' responsiveness toward their voters.

\footnotetext{
${ }^{7}$ It is Bangladeshi currency. 1 US Dollar $=84.64$ Taka while 1 Taka $=0.012$ US Dollar.

${ }^{8}$ Hygiene, sanitation and water supply project of donor agency.

${ }^{9}$ According to Section 39 of the UP Act 2009, a vote of 'no confidence' can be passed by UP members against UP chairs or members by the UP.
} 
As one respondent reported:

We, the UP members, did not attend the discussion on budget review at the UP premises. A project that was shortlisted and displayed at [the] OBM for people's information was not implemented by the UP chair. It seems that the allocations, including Annual Development Programme [funds] and revenue earnings of [the] UP are in his possession. The UP chair considers himself all in all. He took projects at his discretion. He appointed contractors without any feasibility analysis for implementation of projects. The fund allocations to the projects did not maintain procurement process as per procurement rules. We, some UP members, placed a 'no confidence' motion against him. But, you know, each member is not the same. We did not have the majority that is required to pass the 'no confidence' motion. So, the decisions were not changed (fieldwork interview, Hariyan UP, 18 January 2014).

Despite the above example, the study findings suggest that where previously spending decisions were the personal prerogative of UP chairs, now money is more likely to be spent according to citizens' priorities, and the pattern of service delivery by UPs has changed slightly. This study found strong evidence that UP funds (including tax revenue, government allocations, donors' allocations etc.) were correctly allocated to those projects which had been selected at WSs. Interviewees who had participated in WSs also reported that project implementation decisions (e.g. road and culvert construction, selection of beneficiary groups to receive fishing nets, location of deep-water wells) were appropriately prioritised in the WS meeting and finalised at the OBM.

\section{Social accountability: trust between electorate and representatives is enhanced}

The participatory processes described above have also helped build capacity and trust. On the one hand, the leadership of the UP officers has provided scope for citizens to access their representatives and raise questions at the OBM. At the same time, having to answer those questions has improved the UP officers' performance. The OBM, as a technique of social accountability mechanism, has provided transparency in the governing process of UPs which had previously been absent. These processes offer a chance, both to the electorate and to UP representatives, to clarify their roles. UP representatives appeared to become more careful about their decision-making and more mindful of the likely reaction of citizens, since these same citizens had access to the decisions and their costs and outputs, and experienced their impact. The process also appeared to enhance citizens' trust in UP officers, since the provision of accurate information prevented the spread of rumours and mistrust. Many of the citizens who participated in OBMs expressed their satisfaction with the OBM process and confidence in their UP leaders.

\section{Funding is increased and spending democratised}

A welcome benefit of the new system was that direct fund transfer to UPs now became viable, due to the greater accountability and participation in decisions over the use of such funds. Previously, when UPs had been one-man bands, direct transfers had been considered unwise and unsafe, on the assumption that corruption could be expected if UPs got large cash injections; as a result, UPs were chronically short of resources. However, the LGSP-II project made large fund transfers to those UPs 
which were using the OBM and PP mechanisms, and disproved this assumption. On the contrary, direct transfer enhanced the functional efficiency of the UPs. As the UP Act 2009 requires that transferring agencies demonstrate a clean audit report on their transfers, UPs had to upgrade their fund management to assure that their audits were clean (Chowdhury 2015). UP secretaries began to maintain proper financial records for their UPs, as required by the auditors. These records included income reports, expenditure reports, minutes of WSs and OBMs, budget copies, project beneficiary lists, project implementation lists, participant lists from WS meetings, and resolutions made by WS and SC meetings.

\section{PP and OBM: ongoing challenges}

Despite the successes outlined above, some obstacles to the smooth operation of PP and OBM remain. These are discussed below.

\section{Limited capacity of UP officers}

This study found that in many cases UP officers are not yet fully capable of carrying out their enhanced responsibilities in the preparation of their UDP (see Figure 3). For example, at Gogram UP the statutory committees were only formed after NGO officials assumed that responsibility. Moreover, none of the PC, SC and UDCC structures were fully worked out (Table 1), nor was any attempt made to analyse the budget further; the UP officers did not have the capacity to do it. Many UP elected officers were also unaware of the need to constitute SCs and UDCCs, and, where these committees did exist, many were unable to arrange meetings with their members (see also Chowdhury 2015).

Figure 3: Participatory budgeting process: contrast between statutory requirements and practice

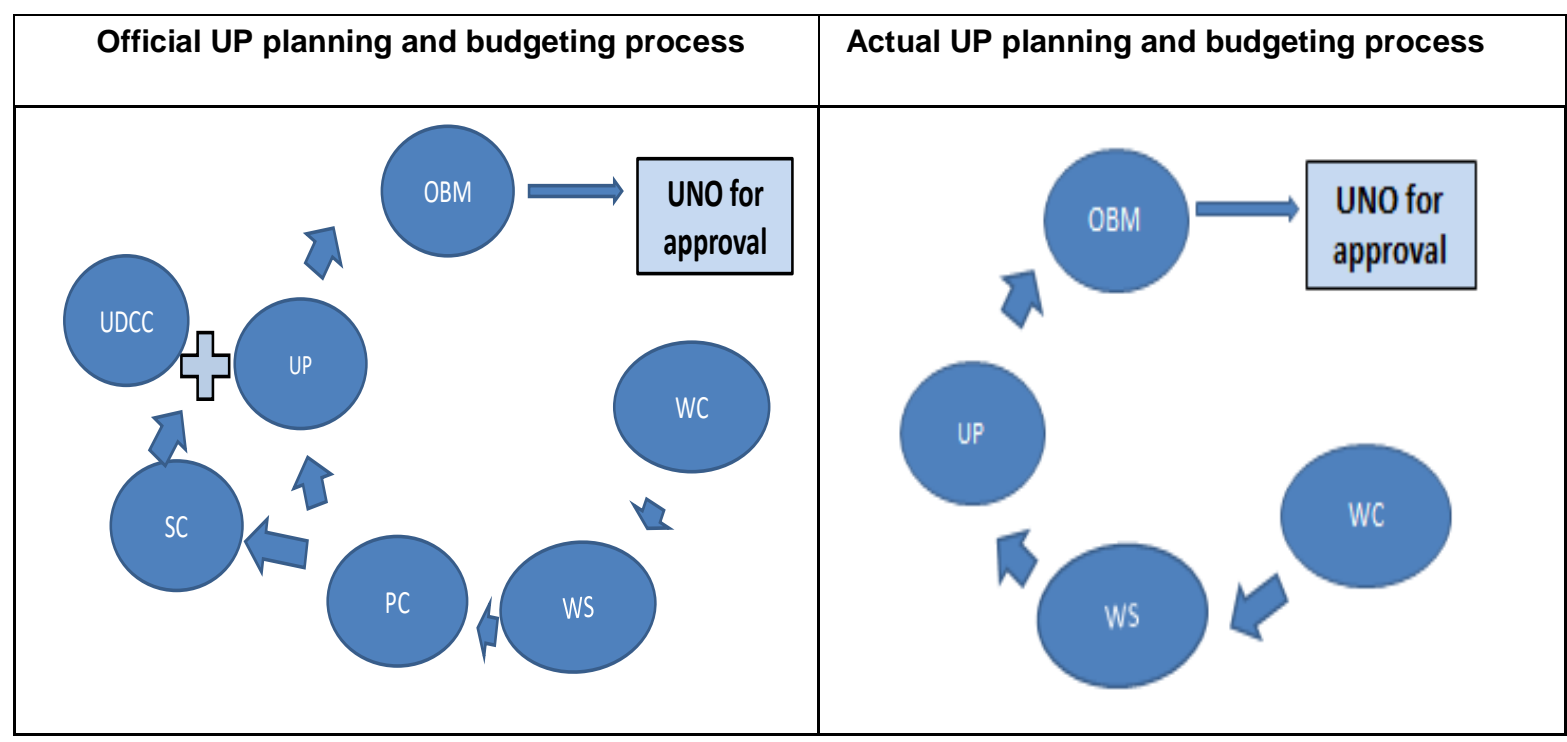

Source: GoB (2012b), modified by author to illustrate actual practice.

Figure 3 shows that plans of WS were shortlisted in the UP meeting. This did not include the formal process of scrutiny of the project implementation feasibility by the members of the other committee including PC, SC and UDCC. As a consequence, the participation of citizens, members of CSOs and 
government officers was often absent in the third stage of PP and OBM. In such cases, UP chairs and their representatives effectively monitored themselves, meaning there was no objective observation of project feasibility. These findings suggest that in these cases local economic development was neither based on cross-boundary coalitions, nor on a development agenda identified by local poor people.

\section{'Bottom-up' funding has no 'up'}

Another finding of this study was that policy, planning and budgeting processes in Bangladesh are fragmented. In the UPs studied, many of the plans selected at WSs and finalised at OBMs remained unimplemented. The intended linkage of policy, planning and budgeting envisioned in the GoB Medium Term Budget Framework (MTBF) often did not happen above the local level (as shown in Figure 3), because the PC, SC, and UDCC were not functioning. In some UPs, these committees existed only on paper (see Table 2). This is of concern, as 'bottom-up' planning can only succeed if the decisions taken at WSs are acted on by the upper levels of the planning process, included in regional and national plans, and funded. Without that action, good ideas were left at the UP level and to the UP's limited funding resources. Commenting on the overall planning and budgeting process, one UNO expressed the following view:

The main intention of the preparation of plans at the WS is neglected at the UZP. The plans that are placed at WS are not being implemented, although the legal provision requires that all plans are to be implemented following the 'bottom-up approach'. At the planning and short-listing stage, deductions were made on projects since the practice is that big projects from the WS are not implemented by the UZP. It is not practised that plans of WS are implemented by ADP at UZP. The political motives and directions of the Member of Parliament (MP) get priority in the implementation of development projects at UZP and $40 \%$ allocation of social safety net programme is utilised by local MPs (fieldwork interview, Raiganj UZP, 29 January 2014).

As a result, too often ideas from the bottom stayed at the bottom and there was no 'up'. Therefore, funding was insufficient to carry out the local plans, as the UP budgets that are sent to UZPs are not given priority by the local offices of government ministries. A knock-on effect was that citizens were denied the opportunity to discuss the draft of their UZP's budget - a process which is supposed to take place in the presence of UP members, municipal councillors, heads of schools, private organisations, banks, entrepreneurs and other members of civil society.

\section{Politics and lack of manpower: plans do not translate into projects}

An additional finding was that citizens' needs tend to be suppressed by local politics. In all the UPs under study the MP, the UZP chair and the UP chair belonged to the same political party. If anyone was able to influence them, it was the ward members, and their impact was limited. The UNO and the MP have enormous power over regulating municipal councils, since the MP advises on matters relating to the UZP and UP, and the UNO authorises UP budgets. 
This study found that elected political leaders showed their loyalty to the local MP and UZP chair by inviting them to the OBM. They did so because their nomination as a candidate for UP election was dependent on support from these people. As a consequence, it was found that the participatory scope for general citizens decreased, because the entire budget session was taken over by political oratory from the national political leaders. These findings substantiate the work of Panday and Asaduzzaman (2011), which indicated that the members of Bangladesh's two major political parties negotiated between themselves to retain control of UP service delivery. Panday and Asaduzzaman (2011) found that 'dalal chokra' (a closed network of mediators/brokers who exploit their positions as ruling party members), and the relatives of, and campaign workers for, the MP or UP chair, have more impact on the day-to-day decision-making of a UP than do PP and OBM. The example of bribery is common in the local level. A participant of FGD stated:

I have given Tk. 2500 to a broker (dalal) to get employment opportunity from the UP Chair. But still now I have not got that work. The broker is the follower of the UP Chair. I neither got any work nor my money back (FGD data, February 06, 2014).

Illustrating this point, one Upazila women's affairs officer (UWAO) said that, although previously willing to do so, she no longer attended WSs or developed projects from UP-level demand lists:

I have been performing my duties as UWAO in two UZPs simultaneously. For the last six years, I have attended various meetings of UPs under my UZP. It is very distressing that, during six years' working experience with these two UZPs, my department has never got any project yet. After UZP elections, I have found that those projects which were regarded as important by the UZP chair got priority for implementation (fieldwork interview, Aditmari UZP, 11 February 2014).

In addition, lack of manpower due to restrictions in central government funds, and lack of local capacity are problems in in both UPs and UZPs. This results in poor supervision and monitoring of UZP officers, and disregard of rules and instructions which are impeding the progress of participatory UP planning and open budgeting. Interviewees commented that it was not possible for the few UZP officers in post, as co-opted members of SCs and UDCCs, to participate in so many committee meetings.

\section{'Mass marketing' fails to bring in enough participants}

Despite apparently extensive efforts to publicise meetings, this study found a lack of understanding among citizens in the villages regarding the planning and budgeting process. The ward members were found to be organising WSs and OBMs, and using various techniques to encourage attendance: invitation letters, mobile loudspeaker announcements, personal contact, mobile telephone calls, messages delivered by chowkiders (village guards) etc. Of these techniques, WS participants reported that direct contact between ward members and their electorate was the most effective. However, despite this 'mass marketing' of opportunities for participation, most villagers did not participate in WSs and many stated that they had not received invitations or information regarding WSs and OBMs. One important issue here may be women's restricted mobility and the purdah system (hiding of 
women) which impedes their participation in the political process. For their part, UP officers insisted they had taken every possible action to recruit participants to the WSs, and attributed the shortfall to lack of personal interest, lack of awareness, political reasons, and time conflicts.

\section{Risk of creating funding dependency}

WSs and OBMs bring the opportunity for additional resources from government and donors; but they also provide an opportunity for local officials to play the system. As a district facilitator of the LGSPII project stated (a view echoed by six UP secretaries):

The formation of [a] WC is obligatory for organising a WS. But a WS is not specifically required to get LGSP-II funds. It offers an opportunity for villagers to express their overall demands relating to their benefits. [But] the LGSP funds have specific utilisation sectors, whereas planning at WS is supposed to cumulate overall development plans of a ward. I have found that most of the UPs are preparing their plans narrowly for getting LGSP funds. But, along with willingness of UP officers, awareness of general people is necessary for people's participation at [a] WS (fieldwork interview, Lalmonirhat district, 13 February 2014).

At present in Bangladesh there is a lack of government initiatives to encourage UPs to generate their own sources of income; and documentary analysis suggests that self-generated sources of UP income have gradually declined over time. Table 5 shows the limited capacity of UPs to generate own-source revenue, and their limited financial capacity to implement all the plans of the WS.

Table 5: Income sources of the six UPs under study (2011-12) (Amount in USD)

\begin{tabular}{|c|c|c|c|c|c|c|c|c|}
\hline UP & $\begin{array}{l}\text { Property } \\
\text { tax }\end{array}$ & $\begin{array}{c}\text { Other tax } \\
\text { income }\end{array}$ & $\begin{array}{c}\text { GoB } \\
\text { contribution } \\
\text { to salaries }\end{array}$ & $\begin{array}{c}\text { Land } \\
\text { Transfer Fund } \\
\text { (property } \\
\text { sales tax) } \\
(1 \% \text { of total) }\end{array}$ & $\begin{array}{c}\text { Funds from } \\
\text { Test Relief/ } \\
\text { Food for Work } \\
\text { programmes }^{10}\end{array}$ & \begin{tabular}{|c|} 
Funds from \\
Annual \\
Development \\
Programme \\
\end{tabular} & EGP11 & $\begin{array}{c}\begin{array}{c}\text { Funds } \\
\text { from } \\
\text { donors/ } \\
\text { NGOs }\end{array} \\
\end{array}$ \\
\hline \multicolumn{9}{|c|}{ Rajshahi District } \\
\hline Gogram & 339.84 & 871.836 & 3327.4 & 2755.2 & 6975.78 & 0 & 35028 & 21672.43 \\
\hline Hariyan & 3112.82 & 3343.02 & 2024.2 & 14484 & 47189.1 & 9600 & 3900 & 16466.39 \\
\hline \multicolumn{9}{|c|}{ Sirajganj District } \\
\hline Ghurka & 2298.72 & 6080.4 & 7481.4 & 12000 & 49776.34 & 2400 & 0 & 0 \\
\hline Hatikumrul & 8228.26 & 2597.43 & 7085.0 & 10800 & 21535.62 & 0 & 0 & 0 \\
\hline \multicolumn{9}{|c|}{ Sirajganj District } \\
\hline Kakina & 6552 & 2244 & 7724.4 & 2400 & 26700 & 3540 & 0 & 14412 \\
\hline Vadai & 761.28 & 152.4 & 4096.5 & 420 & 0 & 5757.32 & 0 & 0 \\
\hline
\end{tabular}

Source: Real expenditure statement review (2014) income

It is evident from interview data that the inhabitants of the Vadai UP did not pay property tax while the sources of income from other sectors were minimal to meet the needs of the citizens. However,

\footnotetext{
${ }^{10}$ Under social safety net programmes such allocations are made by GoB for poor, ultra-poor and marginalised sections of society.

${ }^{11}$ Employment Generation Programme. Allocations under this programme were made in Sirajganj district to support employment generation for people affected by river erosion.
} 
Chowdhury and Panday (2018) found that fund mobilisation was dependent on the personal motive and efficiency of the UP chair. UP chairs who were not elected from the ruling political party acted as inactive parts of the resource mobilisation process. As an outcome funding from donors and government vary from UP to UP. Nor may UPs keep the income from all sources within their boundaries. The interference of central government is an obstacle to UPs in generating revenues; for example, UPs receive only $1 \%$ of taxes raised from land transfers in their area, with the rest of the charges being remitted to central government. The allocation of funding from the Annual Development Programme (a national fund to promote economic development) is also rarely available for development plans put forward by the UZP and UP. For example, according to a 2017 report by the newspaper The Daily Star, in 2013-14 only 1.24\% (approx. 1,570 million USD) of the GoB budget was allocated to LGIs. Generally, there is a scarcity of data about the revenue received by LGIs from national government. Nor do all UPs receive equal funding from donors or NGOs.

In some UPs where there is no fund allocation other than LGSP-II funds, the UP functionaries did not organise a WS. The following opinion of a female ward member is indicative. Raising the issue of scarcity of resources, she commented:

I am a member of several standing committees of the UP. After taking [my] oath [of service], I have organised meetings of the SC (agriculture, fisheries \& livestock and other economic development projects) ensuring involvement of general people, as I am the chair of that SC. My question is: what [can] I do if I do not have allocation of funds for project implementation? (fieldwork interview, Hariyan UP, 17 January 2014).

The UP Act 2009 has empowered UPs to generate revenue from many local sources, including local tax, marketplaces and open water bodies, and even renting out a part of their facilities, but these sources are not enough to secure financial autonomy. In some UPs, no income was generated from these sources. A key problem is the lack of capacity among UP officers to identify and develop valid databases of possible tax sources.

\section{Discussion and conclusion}

Processes such as PP and PB, and the slightly narrower approach of OBM, adopted by UPs, should not be adopted just because they sound good, because other countries are doing them, or because donors are pushing for them. They should be adopted because they can help to reduce national and individual poverty, in line with the UN Sustainable Development Goals. This study indicates that an effective OBM process, as part of PP, has strong potential in Bangladesh if it can involve the true 'experts', the rural poor, in solving their own problems. However, PP and OBM are not yet reaching this goal in Bangladesh. Considering the four types of decentralisation discussed in this paper's introduction, the author found that fiscal and administrative power were not transferred to the UPs. This being the case, equitable development could not be expected merely by devolving political power for prioritising local needs and engaging donors/NGOs in limited development activities. 
This study found that citizens are fully able to identify their priorities, and large cash injections have brought beneficial financial reforms in the LGIs of Bangladesh. There are also opportunities to implement policies/plans/projects for improving the livelihoods of the poor via direct allocations to LGIs from central government. However, Bangladesh's disjointed central planning system is still an impediment to development.

Furthermore, citizens are less interested in learning about rights, the fiscal responsibility of the government, or broader social policies than they are in obtaining a small infrastructure project that will benefit them. In addition, there is a risk that if citizens' demands are not implemented they will feel ignored and the members of a community group will stop participating. Thus, fiscal and administrative decentralisation are essential to achieve a participatory and accountable government system at the local level.

Finally, there is a need for an independent commission on LGIs which can suggest viable strategies including unified policies for local plan preparation, approaches for project implementation, monitoring of the planning and budgeting process from the government side, and the collation of revenue and expenditure data to inform the democratisation of local-level planning in Bangladesh.

\section{Declaration of conflicting interest}

The author declared no potential conflicts of interest with respect to the research, authorship, and/or publication of this article.

\section{Funding}

This paper is drawn from $\mathrm{PhD}$ research, which was funded by a fellowship from the Prime Minister's Office Fund for Higher Education, Bangladesh.

\section{References}

Ahmed, T. (2012) Decentralisation and the local state: Political economy of local government in Bangladesh. Dhaka: Agamee Prakashani.

Bergh, S. (2004) Democratic decentralisation and local participation: A review of recent research. Development in Practice, 14 (6), 780-790. https://doi.org/10.1080/0961452042000284012

Cabannes, Y. (2015) The impact of participatory budgeting on basic services: municipal practices and evidence from the field. International Institute for Environment and Development, 27 (1), 257-284. https://doi.org/10.1177/0956247815572297

Cheema, G.S. and Rondinelli, D.A. (1983) Implementing decentralisation policies: An introduction. In: Cheema, G.S. and Rondinelli, D.A. (eds.) Decentralisation and development: Policy implementation in developing countries. (pp. 9-34). Beverly Hills, Calif.: SAGE. https://doi.org/10.3828/twpr.7.1.hp452j5524582577

Cheema,G.S. and Rondinelli, D.A. (2007) From government decentralisation to decentralized governance. Available at: http://muse.jhu.edu/chapter/1068633 [Accessed 1 May 2013].

Chowdhury, S. (2015) Impact of 'the Local Government (UP) Act, 2009' on the local governance in Bangladesh: A focus on people's participation and accountability. Unpublished PhD Thesis, Department of Public Administration, Rajshahi University, Rajshahi. 
Chowdhury, S. and Panday, P.K. (2018) Strengthening local governance in Bangladesh: Reforms, participation and accountability. USA: Springer.

European Commission. (2007) Supporting decentralisation and local governance in third countries. Tools and Methods Series, Reference Document No 2. Brussels: Europe Aid Corporate Office.

Government of Bangladesh. (2009) The Local Government (UPs) Act 2009. Dhaka: Government of Bangladesh.

Government of Bangladesh. (2012a) The UP operational manual. Dhaka, Bangladesh: Local Government Division.

Government of Bangladesh. (2012b) Budget booklet 2012-13. Dhaka: Finance Division, Ministry of Finance.

Government of Bangladesh. (2013) The union parishad (development plan) Circular 2013. Dhaka, Bangladesh: Local Government Division.

Malena, C., Forster, R. and Singh, J. (2004) Social accountability: An introduction to the concept and emerging practice. Social Development Paper No. 76. Washington: The World Bank.

Mulgan, R. (2002) Accountability issues in the new model of governance. Discussion Paper No 91. Australian National University (ANU): ANU Press Przeworski, Stokes.

Obaidullah, A.T.M. (1999) Bangladesh public administration: Study of major reforms, constraints and strategies. Academic Press and Publishers Ltd. Dhaka.

Olsen, H.B. (2007) Decentralisation and local governance, Module-1: Definitions and concepts. Concept Paper on decentralisation and local governance. Available at: https://www.eda.admin.ch/dam/deza/en/documents/Publikationen/Diverses/167288-decentralisationlocal-governance_EN.pdf [Accessed 14 May 2018]. https://doi.org/10.1017/cbo9780511756139.004

Panday, P.K. and Asaduzzaman, M. (2011) Politics, problems and trends of decentralized local governance in Bangladesh. In: Jamil, I., Aminuzzaman, S.M., Askvik, S. and Haque, S.T.M. (eds.) Understanding governance \& public policy in Bangladesh (MPPG programme). (pp. 153-174). Bangladesh: North South University.

Rahman, A. (2005a) Effective participation: Community engagements in participatory budgeting in Bangladesh. Shahbag, Dhaka: Unnayan Shamannay.

Rahman, A. (2005b) People's budgeting at the local government level in Bangladesh. In: United Nations participatory planning and budgeting at the sub-national Level. Manila, Philippines: Department of Economic and Social Affairs, United Nations.

Rosenbloom, D.H. (1989) Public administration: Understanding management, politics, and law in the public sector. $2^{\text {nd }}$ Edition. Singapore: McGraw-Hill International Editions.

Sarkar, S.K. and Dutta, A. (2011) Country paper: Bangladesh, democratic accountability in local government institutions. In: Democratic accountability in local governance: Experience from South Asia. (pp. 36-66) New Delhi-110062: Pria Global Partnership.

Shah, A. (2007) Participatory budgeting. Public Sector Governance and Accountability series. Washington, DC: The World Bank.

The Daily Star. (2017) Local government and economic empowerment. February 27, Dhaka. Available at: http://www.thedailystar.net/towards-just-and-inclusive-society/local-government-and-economicempowerment-1367632 [Accessed 07 May, 2017].

Ullah, M.A. and Pongquan, S. (2011) Revenue mobilization performance of UP in Bangladesh: Is it convergence of central-local relations. Asian Social Science Journal, 2, pp. 25-40. https://doi.org/10.5539/ass.v7n2p25

Vijayalakshmi, V. (2002) Gender mainstreaming in Sirajganj local governance development project. Nagarbhavi, Bangalore, India: Institute for Social and Economic Change.

WahedUzzaman, W. and Alam, Q. (2015) Democratic culture and participatory local governance in Bangladesh. Local Government Studies, 41 (2), 260-279. https://doi.org/10.1080/03003930.2014.901217

Wampler, B. (2007) A guide to participatory budgeting. In Shah, A. (ed.) Participatory budgeting. Public Sector Governance and Accountability series. Washington, DC: The World Bank. 
World Bank. (1998) Public expenditure management handbook. Washington, DC: World Bank. https://doi.org/10.1596/0-8213-4297-5

Yuliani, E.L. (2004) Decentralization, deconcentration and devolution: What do they mean? Available at: http://www.cifor.org/publications/pdf_files/interlaken/Compilation.pdf [Accessed 24 April 2017]. 